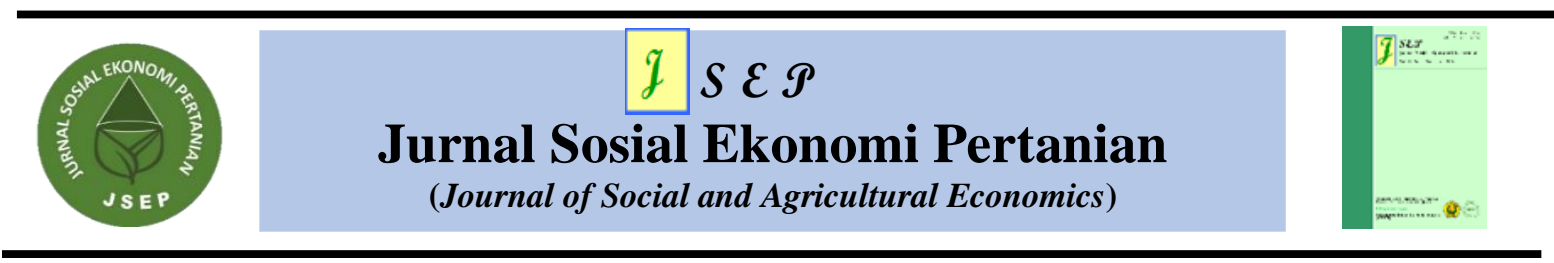

\title{
LEVEL OF FAILURE RISK BASED ON LAND TYPOLOGY OF PARTICIPANTS OF RICE FARM INSURANCE PROGRAMS IN SOUTH SUMATERA
}

\section{TINGKAT RISIKO KEGAGALAN BERDASARKAN TIPOLOGI LAHAN PETANI PADA PROGRAM ASURANSI USAHATANI DI SUMATERA SELATAN}

\author{
Dwi Kuncorojati ${ }^{*}$, M. Yamin ${ }^{1}$, \& Yunita $^{1}$ \\ ${ }^{1}$ Master's Degree Program in Agribussiness, Sriwijaya University, Indonesia \\ *email:Dw7kuncoro@gmail.com; Telp: 08117885567
}

\begin{abstract}
Risk level in South Sumatra differs based on the land typology in which Buay Madang Timur District in East OKU Regency with typical irrigation rice field typology has different risk level compared to Banyuasin Regency with its tidal land typology. This research was aimed to find out risk failure in two land typologies had losses due to its risk. The calculation of Z score was used to calculate risk level using cross data section in year 2019. Data were collected from each district with 120 AUTP farmer participants consisted of 60 samples of tidal land typology and 60 technical irrigation. Which 60 samples consisted of 52 unclaimed farmers and 8 claimed farmers. Based $Z$ score calculation of crop failure risk, it was resulted that technical irrigation land typology in OKU Regency had 44\% risk level due to rat and planthopper attack, compared to $49 \%$ tidal land typology in Banyuasin Regency that caused rat attack. Risk impact due to crop failure was then calculated using the Value at Risk (Var) method. Results showed that crop failure losses in East OKU Regency were equal to Rp. 11.304.361,- for each planting season while in Banyuasin Regency it was Rp. 12.445.273,-. Thus, the impact of crop failure risk in tidal land typology was greater than technical irrigation.
\end{abstract}

Keywords: insurance, rice farm insurance, risk

\begin{abstract}
Tingkat risiko gagal panen peserta AUTP berdasarkan tipologi lahan Sumatera Selatan berbeda beda, untuk tipologi lahan irigasi teknis di Kabupaten OKU Timur dan tipologi lahan Pasang Surut di Kabupaten Banyuasin, Penelitian ini bertujuan untuk mengetahui tingkat risiko kegagalan pada kedua jenis lahan, lahan irigasi dan pasang surut. Perhitungan $Z$ score digunakan untuk menghitung resiko dengan menggunakan data tahun 2019. Pengambilan sampel data dari masing-masing kecamatan dengan 120 petani peserta AUTP terdiri dari 60 sampel tipologi lahan pasang surut dan 60 tipologi sawah irigasi teknis, Setiap sampel terdiri dari 52 petani yag tidak klaim dan 8 petani yang klaim. Berdasarkan perhitungan $Z$ score risiko gagal panen, diperoleh hasil tipologi lahan irigasi teknis memiliki tingkat risiko 44\% akibat serangan tikus dan wereng dibandingkan dengan 49\% tipologi lahan pasang surut yang disebabkan oleh serangan tikus. Dampak risiko akibat gagal panen kemudian dihitung dengan menggunakan metode Value at Risk (Var). Hasil penelitian menunjukkan bahwa kerugian gagal panen pada tipologi sawah irigasi teknis sebesar Rp. 11.304.361, - untuk setiap musim tanam sedangkan pada tipologi lahan pasang surut sebesar Rp. 12.445.273, -. Dengan demikian, tingkat risiko dan dampak kerugian gagal panen pada tipologi lahan pasang surut lebih besar dari pada tipologi irigasi teknis.
\end{abstract}

Kata kunci : asurasi, asuransi usahatani padi, risiko

How to Cite: Kuncorojati, D, Yamin, M., \& Yunita. (2021). Level of Failure Risk Based on Land Typology of Participants of Rice Farm Insurance Programs in South Sumatera. JSEP: Jurnal Sosial Ekonomi Pertanian, 14(1): 11-18. 


\section{INTRODUCTION}

Rice is one of the most important food crops in supporting food needs which is a staple food source for most Indonesians as well as a strategic commodity. The role of rice farming in meeting Indonesia's food needs is always associated with its high risk of uncertainty (Pasaribu et al., 2010). According to (Ramadhana and Raihan, 2013) the risk of uncertainty includes the level of crop failure is caused by both internal and external factors, the internal factor comes from the farmer himself, while the external factor comes from nature in the form of climate change and the attack of plant pest organisms (OPT). External factors have a bigger influence than internal factors that cause great concern for rice farmers, including climate change which has a significant effect on crop failure.

Crop failure generally occurs due to the long-term rainy season which results in inundation of the land due to flooding in the long term, it damages the irrigation channels during the dry season which causes drought, as well as pest and pest attacks that farmers cannot control. The various risks faced in the agricultural sector have an impact on the stability of farmers 'income, therefore one of the important challenges for the agricultural sector is how to increase farmers' income. In this context, the government is expected to take part in providing protection and empowerment to farmers who play a role in agricultural development to realize food sovereignty, food self-sufficiency, and food security in a sustainable manner.

Law number 19 of 2013 concerning farmer protection and empowerment, has been followed up with the issuance of agricultural regulation number 40 of 2015 concerning agricultural insurance facilitation. Agricultural insurance is a transfer of risk to protect farming by providing compensation to crop failure that caused by the risk of drought, flooding, and pest and disease attacks from those occur while farming so that the sustainability of farming can be guaranteed. One form of agricultural insurance that has been implemented in Indonesia is Paddy Farm Insurance (AUTP) (Daniar and Astrika, 2018).

The AUTP program provides guarantees against crop failure that caused by climate change such as floods, drought, as well as pests and plant diseases, or plantdisturbing organisms. The provision of AUTP is intended to protect the loss of economic value of rice farming due to crop failure, so farmers have working capital for the next planting season. The purpose of this AUTP are: 1) providing protection to farmers in the event of crop failure due to flooding, drought, and pest and diseases attacks to other parties through insurance coverage, and 2) switching losses to farmers (Pertanian, 2016).

South Sumatra Province is one of the provinces that became the pilot project area for rice farm insurance (AUTP) in 2012 and 2013, to be precise, in East OKU Regency with a target of 1000 ha but due to the lack of socialization from the government and the low level of public awareness of insurance, the land area for farmers participating in the AUTP program is only 152.25 ha and is claimed 18.75 ha (Insyafiah and Wardhani, 2014). After that, the expansion of the AUTP pilot project in South Sumatra Province was still implemented from 2015 to 2018 with various districts/cities with subsidies paid by the Ministry of Agriculture on the condition that following AUTP is a rice field with technical irrigation waters so that in South Sumatra it can only be implemented in two districts, namely East OKU Regency and Banyuasin. From 2016 the AUTP program has been facilitated by allowing all land typologies to participate in this program. Each typology of paddy fields in South Sumatra has different risks divided into four, namely irrigation, swamps, tides, and rainfed (Sari, 2019). 
The realization of AUTP in 2018 was only 61.60 percent in South Sumatra (PT Jasindo Palembang Branch Office, 2018). The scheme implemented is that farmers pay 20 percent (Rp. 36,000 per ha) of the total premium (Rp. 180,000) and the remaining 80 percent subsidy (Rp. 144,000) is paid by PT PUSRI through Corporate Social Responsibility (CSR) funds, the area of rice planted. in South Sumatra Province that participated in the AUTP in 2018 as many as 2.85 percent of $620,087.5$ ha, this shows that there are still many rice fields planted with rice in South Sumatra Province that has not participated in this AUTP program. There are two districts with the largest rice field area that participated in the 2018 AUTP, namely Banyuasin Regency with 9,218.5 ha and East OKU Regency 2,565.18 ha with the highest claimed rates (Kurniawan, Thony and Ahmadi, 2019). The realization of AUTP claimed in the two districts decreased in 2018 and was lower than in 2017. The AUTP program is a government program in agriculture that is very important because it can protect the impact of the risk of crop failure that is often faced by farmers face climate uncertainty and pest attacks. As in 2017, the number of claims that have increased greatly in South Sumatra Province indicates a failure in farming rice in several districts. With the AUTP, it is hoped that it can provide a solution to reducing production yields and decreasing farmer income levels. Therefore, researchers are interested in compiling a study entitled "Crop Failure Risk Levels based on land typology of AUTP Program Participants in South Sumatera. The novelty of this research is that the level of risk is differentiated based on land typology, namely the typology of technical irrigated land and tidal land.

\section{METHODOLOGY}

\section{Time and Place}

The study was conducted in East OKU Regency and Banyuasin Regency, the selection of this location was carried out deliberately with the consideration that these two districts had a high rate of crop failure claims and based on the South Sumatra Agriculture Office, the two districts had the highest realization rates for AUTP in South Sumatra with Different land typology, East OKU District with Technical Irrigation Paddy Field Typology while Banyuasin with a Tidal Land Typology. Data collection was taken from January 2019 to February 2020.

\section{Research Methods}

The sampling method used in this study is a disproportionate stratified random sampling method. The sample farmer layers were consisted of farmers participating in the AUTP program with Technical irrigation Land Typology in East OKU District, East Buay Madang District and Tidal Typology in Banyuasin Regency, Muara Padang District. From the land typology, it is divided into unclaimed farmers and claimed farmers to see the probability of the risk level. Sampling based on the land typology of the AUTP program participants can be seen in Table 1 .

Based on Table 1. The total population of farmers participating in the AUTP with Technical Irrigation land typology are 616 people that consisted of 532 claimed farmers and 84 unclaimed farmers. While the number of AUTP participants in the Tidal typology are 287 people with 250 unclaimed farmers and 37 claimed farmers. The total populations were 903 people and the total samples were 120 people. 
Table 1. Sample Farmers in Land Typology Based on The Participation in AUTP Program.

\begin{tabular}{|c|c|c|c|c|c|c|c|}
\hline \multirow[t]{2}{*}{$\begin{array}{l}\mathrm{N} \\
\mathrm{o}\end{array}$} & \multirow{2}{*}{ Sample farmers } & \multicolumn{2}{|c|}{$\begin{array}{l}\text { Number of } \\
\text { populations }\end{array}$} & \multicolumn{2}{|l|}{$\begin{array}{l}\text { Number of } \\
\text { samples }\end{array}$} & \multicolumn{2}{|c|}{ Percentage (\%) } \\
\hline & & $\begin{array}{l}\text { Technica } \\
\text { Irrigation }\end{array}$ & $\begin{array}{l}\text { Tidal } \\
\text { Land }\end{array}$ & $\begin{array}{l}\text { Technical } \\
\text { Irrigation }\end{array}$ & $\begin{array}{l}\text { Tidal } \\
\text { Land }\end{array}$ & $\begin{array}{l}\text { Technical } \\
\text { Irrigation }\end{array}$ & $\begin{array}{l}\text { Tidal } \\
\text { Land }\end{array}$ \\
\hline 1. & Unclaimed farmers & 532 & 250 & 52 & 52 & 9,77 & 20,80 \\
\hline 2. & Claimed farmers & 84 & 37 & 8 & 8 & 9,52 & 21,62 \\
\hline 3. & $\begin{array}{l}\text { Number of } \\
\text { population/ sample }\end{array}$ & 616 & 287 & 60 & 60 & 9,74 & 20,90 \\
\hline & Total & & 903 & & 120 & & 13,28 \\
\hline
\end{tabular}

Source: Secondary Processed Data (2019)

Based on research objective (1), which was to study risk level of crop failure in AUTP participation in South Sumatera, risk level then was calculated based on (Saragih, Chalil and Ayu, 2018) as the following in (1).

$$
\mathbf{z}=\frac{\mathbf{Y}-\overline{\mathbf{x}}}{\mathbf{s}}
$$

Note:

$\mathrm{Z} \quad=$ Risk level of crop failure

$\mathrm{S}=$ Deviation standard of crop failure loss

$\overline{\mathrm{x}} \quad=$ Average value of actual productivity ( $\mathrm{Kg} / \mathrm{ha} /$ Planting season)

$\mathrm{Y}=$ Risk threshold is the amount of tolerated yield loss by the farmers to still be able to fund the next planting season $(\mathrm{Kg} / \mathrm{ha} /$ Planting season)

By Formula (2):

Note:

$$
\mathbf{Y}=\frac{\text { BRTP }}{G K P}
$$

BRTP $=$ Average cost Production $(\mathrm{Rp})$

$\mathrm{GKP}=$ Cropped dry grain $(\mathrm{Rp} / \mathrm{kg})$

Criteria: The risk level limit of $40 \%$ so that the level $>40 \%$ will be classified as a high risk level while $<40 \%$ will be classified as a low risk level (Saragih, Chalil and Ayu, 2018).

For research objective (2) which was to study the impact of crop failure on AUTP (Rice Farmers Insurance) participants in technical irrigation fields in South Sumatera, Value at Risk (VaR) methods can be calculated by using the following formula (3):

Note:

$$
\operatorname{VaR}=\overline{\mathbf{x}}+\mathbf{Z}\left(\frac{\mathbf{s}}{\sqrt{\mathbf{n}}}\right)
$$

$\mathrm{VaR}=$ The impact of losses due to crop failure (Rp/ha/Planting Season)

$\overline{\mathrm{x}} \quad=$ Loss average value of crop failure risk ( $\mathrm{Rp} / \mathrm{ha} /$ Planting Season)

$\mathrm{Z}=\mathrm{Z}$ value of normal distribution table with $\alpha=5 \%$

$\mathrm{S} \quad=$ Deviation standard of crop failure loss

$\mathrm{n} \quad=$ Number of samples

The calculation of crop failure risk was determined by using $95 \%$ of certainty level and $5 \%$ of error. 


\section{RESULTS}

Differences in risk levels of the AUTP program participants in 2019 were considered by the difference between standard and actual productivity. it was found that the risk threshold for technical irrigated rice fields typology was $2.175 \mathrm{~kg}$, to tolerate the production costs for next planting season with revenue tolerance limit of Rp.8.700.000 and with Rp.4,000,- of dried unhusked rice average price. While for tidal typology in Banyuasin Regency, the risk threshold was $4.281 \mathrm{~kg}$ to tolerate production costs for the next planting season with the tolerance limit for the occurrence of level possibility of income was Rp.17.124.000.kg.

The calculation of crop failure risk level of AUTP program participants in Buay Madang Timur of East OKU Regency with technical irrigation land typology and in Banyuasin Regency with tidal land typology can be seen in the following Table 2 .

Table 2. The level of risk for crop failure of AUTP participants based on land typology.

\begin{tabular}{|c|c|c|}
\hline Description & $\begin{array}{l}\text { Technical } \\
\text { Irrigation }\end{array}$ & Tidal Land \\
\hline $\begin{array}{l}\text { 1. } \overline{\mathrm{x}}=\text { Average loss of crop failure }(\mathrm{Kg} / \mathrm{ha} / \\
\text { Planting Season) }\end{array}$ & 327 & 394 \\
\hline 2. Deviation Standard (kg/ha/Planting season) & $1.124,20$ & $1.044,90$ \\
\hline 3. Y (The risk threshold) $(\mathrm{Kg})$ & 2.302 & 1.181 \\
\hline 4. $\mathrm{Z}=\mathrm{Z}$ value of normal distribution table & 1,76 & 3,72 \\
\hline 5. N (Sample farmers) & 60 & 60 \\
\hline 6. Risk Level (\%) & 44 & 49 \\
\hline
\end{tabular}

Source: Secondary Processed Data (2019)

The risk analysis is carried out to find the risk level of crop failure that is detrimental to rice farmers participating in AUTP. Typology of technical irrigation and Tidal land showed that crop failure results from the risk of rice production is $44 \%$ by technical irrigation and $49 \%$ by tidal land. For technical irrigation land typology with a $\mathrm{Z}$ value of 1,64 with a positive sign indicating that the decline in rice production is to the right of the average normal distribution. So that through the $\mathrm{Z}$ table, it is obtained the number 0,44 which is the opportunity value of risk in rice production, while in the tidal typology the $\mathrm{Z}$ value is 3,72 with a positive sign indicating that the decline in rice production is to the right of the average normal distribution. So that through table $\mathrm{Z}$, the number 0,49 is obtained which is the level of risk of crop failure on rice production. This typology is classified as a high risk level for crop failure because it is above $40 \%$.

In the tidal land, the risk level is greater than the technical irrigation typology due to the peculiarity of the tidal soil typology which is high in acidity and the irrigation system for paddy fields is inadequate so that yields are not optimal for pests that make crop failure caused rats because the location of the rice fields is close to land for oil palm, rubber plantations, and a lot of undeveloped lands. Whereas in the technical irrigation typology for soil and water systems it is good, while for planthoppers and rats. In the tidal typology the risk level is greater than the technical irrigation typology due to the peculiarities of the tidal typology, including constraints of low soil fertility, presence of pyrite, high levels of $\mathrm{Al}, \mathrm{Fe}, \mathrm{Mn}$, organic acids, $\mathrm{P}$ deficiency, poor base cations such as Ca, K, Mg, and suppressed microbial activity (Arsyad, Saidi and Enrizal, 2014), high soil acidity (low PH) so it takes efforts to neutralize soil acidity. In this regard, the land is affected by seawater intrusion, there is a shallow pyrite layer which is a threat because it 
can poison the plant root system which is very poor in nutrients so that it requires a higher fertilization dose (Ak and Novitarini, 2020) inadequate, and unpredictable tidal dynamics of water puddles that can cause crop failure $m$ or crop failure, so farmers need assistance in optimization of swampland in addition to assistance for water processing inputs in the form of pump infrastructure development, electricity, main drainage channels, connectivity channels, tertiary channels, worm channels, water gates, dividing boxes, embankments/troughs helping farmers increase yields.

The pests that cause crop failure are rats because the rice fields are close to oil palm, rubber plantations, and a lot of undeveloped scrubland. Whereas in the technical irrigation typology for soil and water systems, it is good because it has irrigation while for planthopper and rat weather. The next step after calculating the risk level of crop failure in the Typology of Technical Irrigation and Tidal land is calculating the impact of the losses on the two typologies of the land.

Table 2. The Results of The Impact of Losses on AUTP Participants Based on Land Typology

\begin{tabular}{lrr}
\hline \multicolumn{1}{c}{ Note } & \multicolumn{1}{c}{$\begin{array}{c}\text { Technical } \\
\text { Irrigation }\end{array}$} & \multicolumn{1}{c}{ Tidal Land } \\
\hline 1. Average loss of crop failure (Rp/ha/Planting & 9.400 .000 & 11.825 .000 \\
season) & 8.967 .292 & 2.920 .739 \\
2. Deviation Standard (Rp/ha/Planting season) & 1.645 & 1.645 \\
3. Z (Table Z) & 11.304 .361 & 12.445 .271 \\
4. VaR (Rp/ha/Planting season) & & \\
\hline
\end{tabular}

Source: Secondary Processed Data (2019)

Table 2 shows the average loss of crop failure by AUTP participants because the production yield experienced by farmers in technical irrigation typology was Rp. 9.400.000/ha/planting season, which means it was lower than the Tidal Typology of Rp. $11.825 .000 /$ ha/planting season, in the calculation of the impact of the loss of crop failure is determined that the confidence level was $95 \%$ and the remaining error was $5 \%$, the distribution value of Table $\mathrm{Z}$ was 1.645, showing the impact of the loss of crop failure calculated through value at risk occurs to every farmer in land typology in technical irrigation was Rp.11.304.361/ha/planting season, this shows the level of losses due to crop failure at the farmer level for each farmer to a maximum value of Rp. 11.304.361/ha/planting season, the magnitude of the impact of losses suffered by farmers is caused by the lack of production for each target by farmers and prices at crop. As for the impact of crop failure losses on Tidal Typology land of Rp. 12.445.271/ha/planting season, this shows the level of losses due to crop failure at the farmer level for each farmer will reach a maximum value of Rp. 12.445.271/ha/planting season. Judging from the magnitude of the impact of crop failure losses Tidal land typology was greater than Technical Irrigation land typology. In Technical Irrigation Typology, the impact of losses is caused by planthoppers, rats and flooding, the way farmers cope with leafhoppers by mass spraying the affected areas, rats with wages and "groboyokan", while the Tidal Typology is caused by pests, how to overcome the impact of losses caused by rat pests is 
with "groboyokan" (Javanese term means working together conducted by farmer to exterminate rats).

\section{CONCLUSION}

The risk level for crop failure of participants in the AUTP Typology of Technical Irrigation was $44 \%$ each hectare each planting season, while the risk level for crop failure in the Typology of Tides was $49 \%$ each hectare each planting season. The loss of crop failure for participants of the AUTP Technical Irrigation Typology was Rp.11.304.361 /ha/planting season, while the typology of tides in was Rp. $12.445 .273 / \mathrm{ha} /$ planting season. Farmers follow AUTP to shift the risk of uncertainty from crop failure. If a crop failure occurred, the compensation money can be used for planting capital in the following season.

\section{REFERENCES}

Ak, A. T. and Novitarini, E. (2020) 'Kajian Usahatani Padi Di Lahan Pasang Surut Dan Penerapan Teknologi Tepat Guna Di Desa Banyuurip Kecamatan Tanjung Lago Kabupaten Banyuasin', Jurnal Agribisnis, 13(Kajian Usaha Tani), pp. 3-11. doi: 10.36085/agribis.v13i2.835.

Arsyad, D. M., Saidi, B. B. and Enrizal (2014) 'Pengembangan Inovasi Pertanian di Lahan Rawa Pasang Surut Mendukung Kedaulatan Pangan (Development of Agricultural Innovations in Tidal Swamp Land for Increasing Food Sovereignt)', Pengembangan Inovasi Pertanian, 7(Pengemb. Inov. Pertan.), pp. 1-8.

Daniar, G. A. and Astrika, L. (2018) 'Implementasi Asuransi Usaha Tani Padi Se-Eks Karesidenan Pati Dalam Mengatasi Gagal Panen (Studi Kasus: Kabupaten Pati dan Kabupaten Rembang)', Departemen Politik dan Pemerintahan Fakultas Ilmu Sosial dan Ilmu Politik Universitas Diponegoro Jl.Prof.Soedarto, (Implementasi Asuransi Usaha Tani), pp. 1-16.

Insyafiah and Wardhani, I. (2014) 'Kajian Persiapan Implementasi Asuransi Pertanian Secara Nasional', Kementerian Keuangan Badan Kebijkan Fiskal, (Asuransi pertanian), p. 75.

Kurniawan, B., Thony, A. and Ahmadi, N. (2019) 'Faktor-Faktor yang Mempengaruhi Keikutsertaan Petani Pada Program Asuransi USaha Tani Padi (AUTP) di Kecamatan Belitang Kabupaten OKU TIMUR', Universitas Sjahyakirti, Palembang.

Pasaribu, S. m et al. (2010) 'Pengembangan Asuransi Usaha Tani Padi untuk Menanggulangi Kerugian 75\% Akibat Banjir, Kekeringan dan Hama Penyakit', Pusat Analisis Sosial Ekonomi dan Kebijakan Pertanian, Kementerian Pertanian, (Pengembangan Asuransi Usaha Tani), pp. 1-22.

Pertanian, D. P. (2016) Pedoman Bantuan Premi Asuransi Usaha Padi, Direktorat Jendral Prasarana dan Sarana Pertanian. Jakarta, Indonesia.

Ramadhana and Raihan, A. (2013) Analisis Risiko Produksi Usahatani Padi Sebagai Dasar Pengembangan Asuransi Pertanian Kasus: Desa Sukaratu, Kecamatan Gekbrong, Cianjur. Institut Pertanian Bogor. 
Saragih, I. R., Chalil, D. and Ayu, S. F. (2018) 'Analisis Risiko Produksi dalam Pengembangan Asuransi Usaha Tani Padi (AUTP) (Desa Panca Arga, Kecamatan Rawang Panca Arga, Kabupaten Asahan)', Jurnal AGRISEP : Kajian Masalah Sosial Ekonomi Pertanian dan Agribisnis, 17(2), pp. 187-196. doi: 10.31186/jagrisep.17.2.187-196.

Sari, Y. I. (2019) Evaluasi Program Usaha Tani Padi Tahun 2018 di Kabupaten Ogan Komering Ilir (OKI). Universitas Sriwijaya. 